\title{
ARRHYTHMIAS AND CARDIAC PACING
}

Prošireni sažetak / Extended abstract

\section{First results of genetic testing in Croatian arrhythmia patients}

Sandro Brusich ${ }^{1 *}$, Maja Dembićc ${ }^{2}$ Zlatko Čubranić1, Paula Hedley², Koraljka Benko², Anting Liu Carlsen $^{2}$, Eduard Margetić ${ }^{3}$, Tam Thanh Pham², Luka Zaputović ${ }^{1}$, Michael Christiansen ${ }^{2}$

${ }^{1}$ University of Rijeka School of Medicine, University Hospital Centre Rijeka, Rijeka, Croatia

'Statens Serum Institut, Copenhagen, Denmark

${ }^{3}$ University of Zagreb School of Medicine, University Hospital Centre Zagreb, Zagreb, Croatia

Objectives: Inherited cardiac arrhythmias are life-threatening syndromes that often occur in young people and are characterized by palpitations, syncope, and an increased risk of sudden death. The etiology can be ion-channel dysfunctions as well as structural heart disease. Common features are single gene mutations that produce the dysfunction, an autosomal-dominant inheritance, incomplete penetrance and variable expressivity. Inherited arrhythmias show marked genetic heterogeneity having multiple types and sites of mutation. Genetic testing is particularly useful as support of the clinical data and in the identification of mutation-carriers that are asymptomatic but may be at risk. We have sought to identify the genetic mutations associated with inherited arrhythmia disorders in a Croatian group of patients and in their relatives in order to identify pathogenic mutations and possible asymptomatic carriers.

Patients and Methods: We have analyzed the DNA from 36 unrelated Croatian patients (50\% female, $41 \pm 16$ years) and 15 close relatives with arrhythmogenic right ventricular cardiomyopathy (ARVC), hypertrophic cardiomyopathy (HCM), long-QT-syndrome (LQTS) or Brugada syndrome (BrS). Only definite clinical diagnoses were accepted. Arrhythmia-related genes were analyzed by polymerase chain reaction (PCR) followed by direct sequencing in the exons and exon-intron boundaries. The control population included 200 healthy Croatian individuals.

Results: In our study we found a high incidence of positive results (24 of 36 probands, 66\%) with a great number of novel mutations (9 out 24 probands, 38\%). This novel variants include: two novel missense mutation in the DSP gene related to ARVC, six novel variants in MYH7, MYBPC3, CSRP3 and TNNI3 genes related to HCM, and two missense mutations in BrS patients.

Conclusions: Genetic investigations of inherited cardiac disorders and the discovery of novel variants are important as they increase our knowledge and understanding of the genetic heterogeneity of these diseases, providing us with valuable information for better patient management. The Croatian population is poorly characterized genetically and initial studies revealed a particularly high number of novel variants $(38 \%)$ indicating that further investigations might discover a great number of new disease-associated variants.

KEYWORDS: genetic testing, inherited arrhythmias, mutation.

CITATION: Cardiol Croat. 2013;8(9):297.

Received: $31^{\text {st }}$ Jul 2013

*Address for correspondence: Klinički bolnički centar Rijeka, Tome Strižića 3, HR51000 Rijeka, Croatia.

Phone: +385-91-5163-466

E-mail: sandro.brusich@gmail.com

\section{Literature}

1. Cerrone M, Napolitano C, Priori SG. Genetics of ion-channel disorders. Curr Opin Cardiol. 2012;27(3):242-52.

2. Hedley PL, Jørgensen P, Schlamowitz S, et al. The genetic basis of long QT and short QT syndromes: a mutation update. Hum Mutat. 2009;30(11):1486-511. 